\title{
Biosynthesis of ZnO Nanoparticles Using Pumpkin Peel Extract (Cucurbita moschata) and its Applications as Semiconductor in Dye Sensitized Solar Cell (DSSC)
}

\author{
Nanda Saridewi ${ }^{1}$, Dzikri Anfasa Firdaus ${ }^{2}$, Isalmi Aziz ${ }^{2}$, Biaunik Niski Kumila ${ }^{3}$, \\ Dasumiati $^{4}$ \\ ${ }^{1}$ Departement of Chemistry Education, Faculty of Educational Science, Syarif Hidayatullah State Islamic \\ University of Jakarta, Indonesia, 15412 \\ ${ }^{2}$ Departement of Chemistry, Faculty of Science and Technology, Syarif Hidayatullah State Islamic University of \\ Jakarta, Indonesia, 15412 \\ ${ }^{3}$ Departement of Physic, Faculty of Science and Technology, Syarif Hidayatullah State Islamic University of \\ Jakarta, Indonesia, 15412 \\ ${ }^{4}$ Departement of Biology, Faculty of Science and Technology, Syarif Hidayatullah State Islamic University of \\ Jakarta, Indonesia, 15412
}

*Corresponding author: nanda.saridewi@uinjkt.ac.id

Received: June 2021; Revision: July 2021; Accepted: September 2021; Available online: November 2021

\begin{abstract}
$\mathrm{ZnO}$ nanoparticles are semiconductor materials that can be used in Dye Sensitized Solar Cells (DSSC). ZnO nanoparticles can be synthesized using pumpkin peel extract (Cucurbita moschata) which functions as a reducing agent, stabilizer, and capping agent. $\mathrm{Zn}\left(\mathrm{CH}_{3} \mathrm{COO}\right)_{2} \cdot 2 \mathrm{H}_{2} \mathrm{O}$ precursor was used with a concentration of

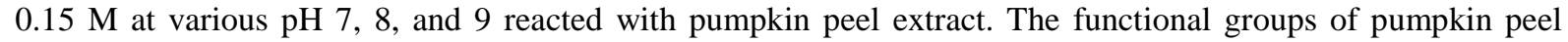
extract were characterized using Fourier Transform Infrared Spectroscopy (FTIR), the samples were analyzed by TEM and XRD. The resulting ZnO nanoparticles were used as semiconductors in Dye Sensitized Solar Cell (DSSC) using dyes from mangosteen peel.The FTIR results showed the presence of functional groups O-H hydroxy, $\mathrm{CH}_{2}$, secondary amides $\left(\mathrm{R}-\mathrm{CO}-\mathrm{NR}_{2}, \mathrm{C}-\mathrm{H}\right.$ and phosphate $\left(\mathrm{PO}_{4}{ }^{3-}\right)$. XRD results showed that $\mathrm{ZnO}$ produced wurzhite crystals with a hexagonal system and the smallest crystal size was $18.99 \mathrm{~nm}$. TEM results showed that $\mathrm{ZnO}$ synthesized at a concentration of $0.15 \mathrm{M}$ and $\mathrm{pH} 8$ had a spherical particle shape with a size of $24.90 \mathrm{~nm}$, while the DSSC test results had an efficiency of $9.06 \times 10^{-4} \%$.
\end{abstract}

Keywords: Biosynthesis, Cucurbita moschata, dye sensitized solar cell (DSSC), ZnO nanoparticles.

DOI: $10.15408 / j k v . v 7 i 2.21046$

\section{INTRODUCTION}

Currently, the use of fossil energy is starting to be minimized, because the supply of fuel reserves tends to decrease. According to the Ministry of Energy and Mineral Resources (2016), Indonesia's oil reserves as of January 1, 2015 , decreased by $1.2 \%$ compared to the previous year of 3.70 billion barrels. On the other hand, the consumption of petroleum has increased. Based on the outlook of the Ministry of Energy and Mineral Resources in 2016, energy demand in 2015 was $876,594 \mathrm{BOE}$, it is estimated that the growth of energy demand in 2025 will increase 1.8 times from 2015 and in 2050 it will increase to 5.5 times (ESDM, 2016).
Semiconductor materials with small band gap energy can be utilized in photovoltaic cells such as dye-sensitized solar cells (DSSC). Dye Sensitized Solar Cell is a generation of solar cells with great potential for the future, because DSSC does not require very pure materials so that it can reduce production costs. The potential of solar energy in Indonesia reaches 207.8 Gigawatts, with an average radiation distribution of $4.8 \mathrm{kWh} / \mathrm{m} 2$.day (Al Hakim, 2020). The dye used is mangosteen peel extract. (Maulina et al., 2014) stated that the antho-cyanin dye of mangosteen peel (Garcinia Mangostana L) produced a fairly large DSSC efficiency of $0.592 \%$. Abdel-latif et al., (2013) investigate the performance of 
dye-sensitized solar cells (DSSCs) based on natural dyes extracted from ten different plant seeds.

$\mathrm{ZnO}$ can be used as a semiconductor material because it shows good optical and electrical properties so that it has good potential applications in electronics, optoelectronics, and sensors. $\mathrm{ZnO}$ as a semiconductor material has high chemical and thermal stability and has a fairly large band gap energy value of $3.37 \mathrm{eV}$. With this large value, the photon energy charge from sunlight will be absorbed by the DSSC. $\mathrm{ZnO}$ nanoparticle synthesis plays a role in reducing the size of the semiconductor in DSSC. The existence of a size effect called the quantum size effect can expand the application of nanomaterials - where the smaller the particle size will increase the energy value of the band gap so that it can increase the efficiency of organic solar cells or DSSC (Gratzel, 2003).

Synthesis of $\mathrm{ZnO}$ nanoparticles can be done by physical and chemical methods. Commonly used physical methods include ball mill, laser ablation, and physical vapor deposition (PVD). These methods require quite expensive equipment and produce limited particle sizes and shapes . Commonly used chemical methods include sol-gel, microemulsion and precipitation methods. The sol-gel method is quite good at producing nano-sized particles. Ningsih et al. (2021) synthesized $\mathrm{ZnO}: \mathrm{Cu}$ by sol-gel methods with different additives (duck egg albumin, monoethanolamine (MEA), and diethanolamine (DEA), where the smallest particles were obtained by adding duck egg albumin with a size of $16.62-53.21 \mathrm{~nm}$. Biological approach through plant extracts as stabilizing agents/surfactants can be used in the synthesis of nanoparticles in order to obtain good characteristics and sizes of nanoparticles. Organisms that play a role in the biosynthetic process include yeast, fungi, bacteria, diatoms, microalgae, cyanobacteria, and plant extracts (Alzahrani, 2015; Parajuli et al., 2020; Mandal et al., 2021).

The biosynthesis of $\mathrm{ZnO}$ nanoparticles has been widely carried out. Several successful studies include: 1) Using Sargassum muticum extract that synthesized $\mathrm{ZnO}$ nanoparticles in spherical shape with particle size of 30-57 nm (Azizi et al., 2014); 2) Nurbayasari et al. (2017) have succeeded in the biosynthesis of $\mathrm{ZnO}$ nanoparticles using Caulerpa sp. with a variation of $\mathrm{pH} 7,8,9$ and a concentration of 0,$05 ; 0,10 ; 0,15 \mathrm{M}$, which obtained the smallest particles at $\mathrm{pH} 8$ and $0.15 \mathrm{M}$, where the average particle size is $370.72 \mathrm{~nm}$; and 3) Saridewi et al. (2021) also perform at the same variation of $\mathrm{pH}$ and concentration, have obtained $\mathrm{ZnO}$ nanoparticles from pumpkin seed extract (Cucurbita moscata) with a particle size of $28.07 \mathrm{~nm}$ at $\mathrm{pH} 8$ and $0,15 \mathrm{M}$.

In this study, biosynthesis of $\mathrm{ZnO}$ nanoparticles was carried out using pumpkin peel extract, where pumpkin peel is an organic waste from pumpkin processing, but still contains metabolites. These metabolites are expected to have functional groups that can act as reducing agents, stabilizers, and capping agents. The resulting $\mathrm{ZnO}$ nanoparticles were used as semiconductors in Dye Sensitized Solar Cell (DSSC) using dyes from mangosteen peel.

\section{MATERIALS AND METHODS Materials}

The materials used in this study were fresh pumpkin peel (Cucurbita moschata) and mangosteen peel extract powder obtained from Ciputat, South Tangerang market. $\mathrm{Zn}\left(\mathrm{CH}_{3} \mathrm{COO}\right)_{2} .2 \mathrm{H}_{2} \mathrm{O}$ (Merck), $\mathrm{NaOH}$ (Merck), ITO glass (Merck), polyethylene glycol (PEG) gel (Merck), $\mathrm{CH} 3 \mathrm{COOH}$ (Merck), Triton-X vl(Merck), Whatman No. 41 filter paper (Merck).

\section{Procedures \\ Simplicia Extract}

Fresh pumpkin peel are dried in the sun. Then it is ground using grinding to form a powder. A total of $10 \mathrm{~g}$ of dried pumpkin peel powder was placed in a beaker and then added as much as $100 \mathrm{~mL}$ of distilled water. Then, a magnetic stirrer was placed in the beaker, and heated in a water bath at $100{ }^{\circ} \mathrm{C}$ for 25 minutes while stirring constantly, at a speed of 4000 rpm. The extract was filtered through Whatman No. 41 filter paper. The pumpkin peel extract obtained was divided into three treatments. The first treatment was pumpkin peel extract used for the biosynthesis of $\mathrm{ZnO}$ nanoparticles. The second treatment was some samples were stored in a cooler until further use. The third treatment for some samples was they were partially dried using a freeze dryer to be tested for their functional groups using FTIR (Azizi et al., 2014). 


\section{Biosynthesis of ZnO Nanoparticles}

$10 \mathrm{~mL}$ of pumpkin peel extract (Curcubita moschata) was reacted with $90 \mathrm{~mL}$ of $0.15 \mathrm{M} \mathrm{Zn}\left(\mathrm{CH}_{3} \mathrm{COO}\right)_{2} .2 \mathrm{H}_{2} \mathrm{O}$ precursor solution. The mixture was placed in a beaker containing a magnetic stirrer and then heated in a water bath at $70{ }^{\circ} \mathrm{C}$ for 1 hour with stirring speed of $4000 \mathrm{rpm}$. Then, $0.1 \mathrm{M} \mathrm{NaOH}$ was added with a mixed $\mathrm{pH}$ variation of 7,8 , and 9 . The sol-gel product formed was then centrifuged at room temperature of $25{ }^{\circ} \mathrm{C}$ at $4000 \mathrm{rpm}$. The precipitate was taken and washed with distilled water. Then, the solid was dried in an oven at $100{ }^{\circ} \mathrm{C}$. The product was roasted at $100{ }^{\circ} \mathrm{C}$ for 18 hours and then calcined in a furnace at $450{ }^{\circ} \mathrm{C}$ for 4 hours to obtain pure $\mathrm{ZnO}$ nanoparticles (Nurbayasari et al., 2017).

\section{Testing the Efficiency of ZnO Nanoparticle Semiconductor Materials on DSSC}

$\mathrm{ZnO}$ paste was made by mixing 1 gram of $\mathrm{ZnO}$ with $4 \mathrm{~mL}$ of acetic acid, stirred for 30 minutes and added by Triton-X, stirred for 30 more minutes. DSSC was assembled first before testing. The ITO glass was cleaned using ethanol and dried at $100^{\circ} \mathrm{C}$ (15 minutes). The substrate was coated with $\mathrm{ZnO}$ paste until evenly distributed. Dry on a hotplate at 30$40^{\circ} \mathrm{C}$ for 1 hour. The substrate coated with $\mathrm{ZnO}$ paste was immersed in a dye solution of mangosteen peel extract for 30 minutes. The $\mathrm{ZnO}$ layer was then covered with a carbon resistance electrode (n-electrode) and clamped on both sides with a sandwich structure. Electrolyte coating of polyethylene glycol (PEG) gel was applied between the two electrodes that had been coated with the PEG polymer gel. The efficiency of DSSC performance was tested through current measurement. The series of DSSC measurements are carried out with a potentiometer, multimeter, and sunlight as a light source (Maryani et al., 2012).

\section{RESULTS AND DISCUSSION}

The FTIR spectrum of Cucurbita moschata pumpkin peel extract showed the main peaks at $3156 \mathrm{~cm}^{-1}-3302 \mathrm{~cm}^{-1}, 2931 \mathrm{~cm}^{-}$ 1, $1560 \mathrm{~cm}^{-1}, 1393 \mathrm{~cm}^{-1}, 1036 \mathrm{~cm}^{-1}$. The presence of functional groups at the peak of $3156 \mathrm{~cm}^{-1}$ indicated the presence of $\mathrm{O}-\mathrm{H}$ functional groups, the range of $3200 \mathrm{~cm}^{-1}-$ $3310 \mathrm{~cm}^{-1}$ indicated the presence of $\mathrm{O}-\mathrm{H}$ groups on polyphenols or proteins/enzymes or polysaccharides/carbohydrates. At a peak of $2931 \mathrm{~cm}^{-1}$ indicated the presence of $\mathrm{CH}_{2}$. At a peak of $1560 \mathrm{~cm}^{-1}$ indicated the presence of a secondary amide (R-CO- $\left.\mathrm{N}_{2}\right)$. At the peak of $1393 \mathrm{~cm}^{-1}$ indicated the presence of $\mathrm{C}-\mathrm{H}$ and at the peak of $1036 \mathrm{~cm}^{-1}$ indicated the presence of phosphate $\left(\mathrm{PO}_{4}{ }^{3-}\right)$ (Skoog et al., 2007). The existence of these functional groups plays a very important role in the nanoparticle synthesis process (Mandal et al., 2021; Parajuli et al., 2020).

Functional groups such as hydroxy $(\mathrm{OH})$ act as stabilizing agents in the biosynthesis of $\mathrm{ZnO}$ nanoparticles. According to Chang \& Waclawik (2012), this functional group acts as a ligand that donates a pair of electrons to the $\mathrm{Zn}^{2+}$ orbital, then $\mathrm{Zn}^{2+}$ and the polar group form complex compounds in nanosized templates. Complex compounds are formed by coordinating covalent bonds between ligands and metals. The ligand will donate a pair of electrons to the metal ion providing the vacant orbital. Metal ions act as Lewis acid, while ligands act as Lewis alkaline. The formed complex compound has a more stable chelating effect. $\mathrm{ZnO}$ nanoparticles were formed after the calcination process. Functional groups from pumpkin peel assisted with $\mathrm{NaOH}$ will reduce $\mathrm{Zn}^{2+}$ ions to $\mathrm{Zn}$ atoms. Then, the $\mathrm{Zn}$ atoms gather and form a $\mathrm{Zn}$ cluster. Further growth occurs where the growth rate will affect the particle size. Functional groups from pumpkin peel extract interacted with the $\mathrm{Zn}$ compound interface and enveloped the $\mathrm{Zn}$ cluster. This event is called 'capping' so that in the formation of $\mathrm{ZnO}$ nanoparticles there is no aggregation between nanoparticles and forms stable $\mathrm{ZnO}$ nanoparticles. This is due to the repulsion between similar charges caused by the hydroxy group $\left(\mathrm{OH}^{-}\right)$which plays a role in binding the $\mathrm{Zn}$ cluster so that the particle interface is enveloped by negatively charged ions (Nurbayasari et al., 2017; Zobel et al., 2015).

The results of the XRD analysis in Figure 2 showed that all samples had the same diffraction pattern and indicated the presence of a $\mathrm{ZnO}$ wurtzite crystal structure with a hexagonal shape. The three variations of $\mathrm{pH}$ had a diffraction pattern in the regions of $2 \theta$ : $31.79^{\circ} ; 34,46^{\circ} ; 36.29^{\circ} ; 47.60^{\circ} ; 56.66^{\circ} ; 62.95^{\circ}$; $66.45^{\circ} ; 68.02^{\circ}$; and $69.18^{\circ}$ with miller index (100) (002) (101) (012), (110), (013), (200), (112), and (201). This is in line with JCPDS no. 9004579 which indicates that biosynthetic 
$\mathrm{ZnO}$ has been formed. The number of $\mathrm{H}^{+}$and $\mathrm{OH}^{-}$ions in solution greatly affects the synthesis of $\mathrm{ZnO}$ nanoparticles. When the $\mathrm{pH}$ is increased and the concentration of $\mathrm{OH}^{-}$ions increases, the density of $\mathrm{H}^{+}$ions decreases compared to when the $\mathrm{pH}$ is acidic. The presence of $\mathrm{OH}^{-}$ions will affect the crystal structure formed. When the concentration of $\mathrm{OH}^{-}$ions is excessive, it will cause the hydrolysis and condensation processes during the synthesis of $\mathrm{ZnO}$ nanoparticles to become increasingly uncontrollable, resulting in nanoparticles with irregular shapes and sizes (Gontijo et al., 2020; Traiwatcharanon et al., 2017; Yazdani et al., 2021). To determine the effect of increasing the concentration of $\mathrm{OH}^{-}$ on the crystallinity of $\mathrm{ZnO}, \mathrm{pH}$ variations were carried out at 7,8 , and 9 .

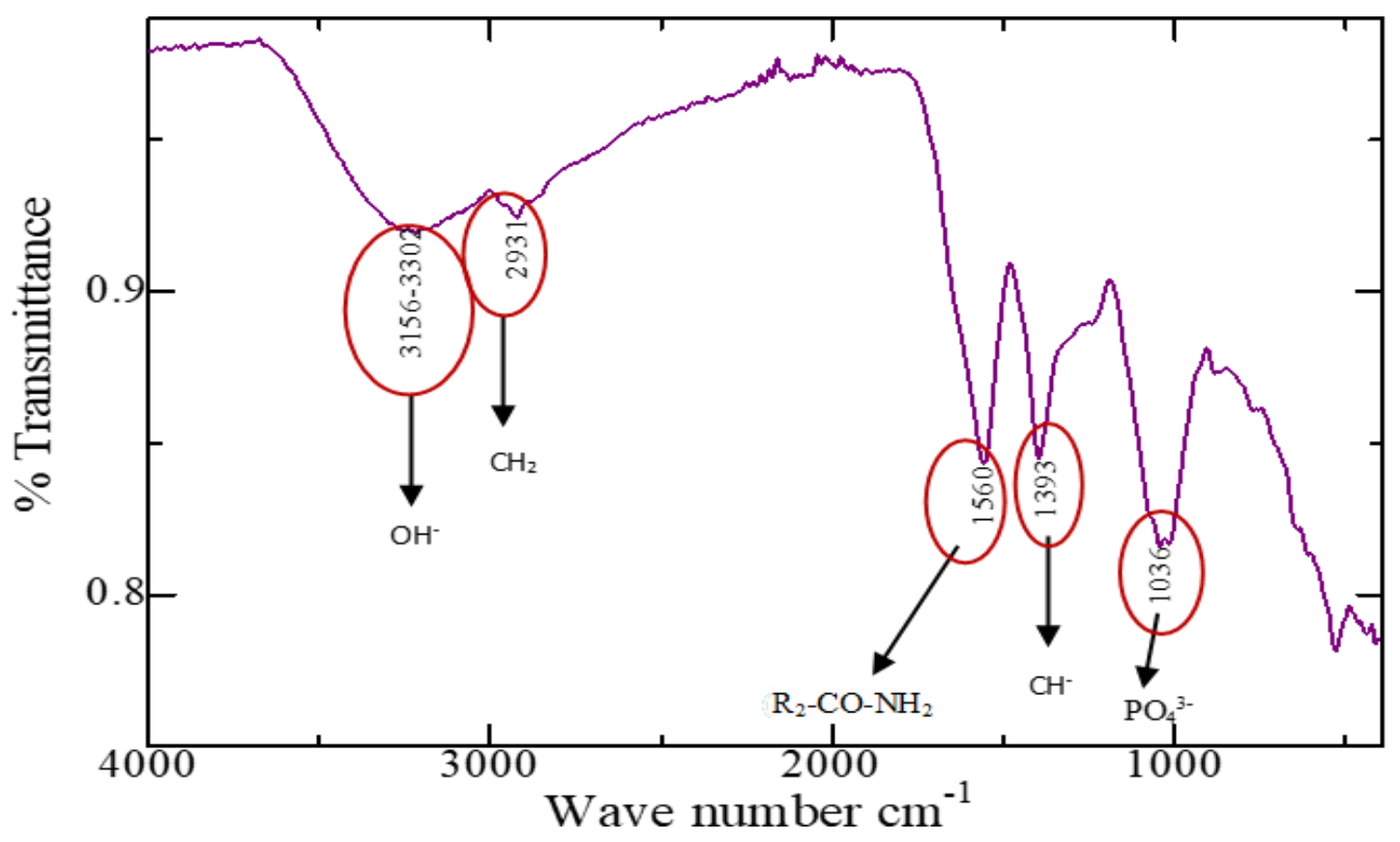

Figure 1. FTIR spectra of pumpkin peel extract

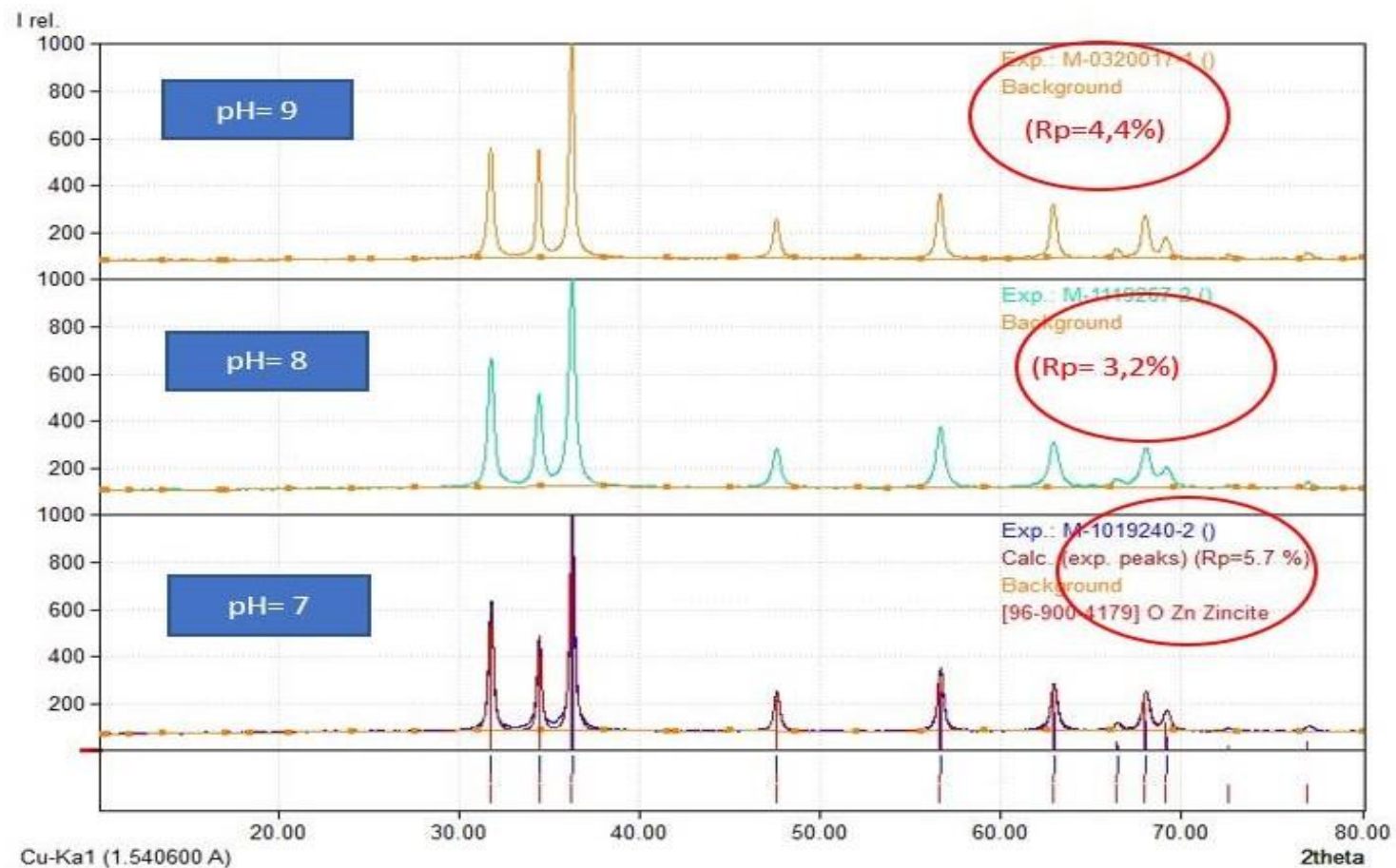

Figure 2. XRD Pattern of $\mathrm{ZnO}$ Nanoparticle with various $\mathrm{pH}$ 
Table 1. Crystal Sizes and Crystal Structures with various $\mathrm{pH}$

\begin{tabular}{cccc}
\hline $\begin{array}{c}\text { Various } \\
\text { pH }\end{array}$ & $\begin{array}{c}\text { Crystal } \\
\text { Structure }\end{array}$ & $\begin{array}{c}\text { FWHM } \\
\left(^{\circ}\right)\end{array}$ & $\begin{array}{c}\text { Crystal } \\
\text { Size } \\
(\mathbf{n m})\end{array}$ \\
\hline pH 7 & Heksagonal & 0.32 & 26.125 \\
pH 8 & Heksagonal & 0.44 & 18.999 \\
pH 9 & Heksagonal & 0.32 & 26.123 \\
\hline
\end{tabular}

The smallest crystal size with a value of $18.999 \mathrm{~nm}$ was obtained at $\mathrm{pH} 8$ with a precursor concentration of $0.15 \mathrm{M}$ $\mathrm{Zn}\left(\mathrm{CH}_{3} \mathrm{COO}\right)_{2} .2 \mathrm{H}_{2} \mathrm{O}$ which was the optimal condition for the biosynthesis of $\mathrm{ZnO}$ nanoparticles. Following Nagarajan \& Kuppusamy (2013) stated that at low $\mathrm{pH}$ the aggregation of $\mathrm{ZnO}$ nanoparticles leads to the formation of larger nanoparticles around the nucleation. $\mathrm{ZnO}$ produced at $\mathrm{pH} 7$ has a larger crystal size of $26.125 \mathrm{~nm}$ compared to $\mathrm{pH} 9$ which is $26.123 \mathrm{~nm}$ which can be seen in Table 1.

The formation of small crystal sizes was strongly influenced by the addition of $\mathrm{NaOH}$ during biosynthesis. The ability of various functional groups to reduce was reduced in the presence of high $\mathrm{H}^{+}$ concentration at low $\mathrm{pH}$ conditions. However, when the $\mathrm{pH}$ is increased, the ability of various functional groups as reducing agents increases, thereby increasing stability and preventing agglomeration as the $\mathrm{OH}^{-}$ion increases (Traiwatcharanon et al., 2017).
To determine the level of accuracy or error rate in matching the diffractogram with a reference data, it is necessary to use a quantitative analysis method using the Rietveld method. Refinement of data is carried out in the Match 3 program to obtain an R-profile value $(\mathrm{Rp})$. For samples with a concentration of $0.15 \mathrm{M}$ at $\mathrm{pH} 7, \mathrm{pH} 8$ and $\mathrm{pH} 9$, respectively, the $\mathrm{Rp}$. values were $5.6 \%, 3.2 \%$, and $4.4 \%$. Putra \& Priyono (2015) stated that the smaller the value of $\mathrm{Rp}$, the higher the purity and the better because the correspondence between theoretical data and observations is higher. In addition, the smaller the value of $\mathrm{Rp}$, the better the resulting crystallinity. The $\mathrm{pH} 8$ sample shows the smallest value of Rp, which can be seen in Figure 2. This shows that $\mathrm{pH} 8$ is the optimal condition, where $\mathrm{ZnO}$ has a smaller crystal size and is purer. Variations in $\mathrm{pH}$ did not affect the crystal structure of $\mathrm{ZnO}$. Therefore, electron microscopy characterization and its application to DSSC were only carried out for $\mathrm{ZnO}$ at $\mathrm{pH}$ 8.

The sample selected is the best sample, i.e. the sample that has the smallest crystal size based on the results of XRD analysis. The sample is $0.15 \mathrm{M} \mathrm{Zn}\left(\mathrm{CH}_{3} \mathrm{COO}\right)_{2} .2 \mathrm{H}_{2} \mathrm{O}$ with $\mathrm{pH}$ 8. Figure 3 shows the size of the synthesized $\mathrm{ZnO}$ nanoparticles that tend to be uniform, the particle size distribution between $12.95 \mathrm{~nm}-46.58 \mathrm{~nm}$ with an average particle diameter of $24.90 \mathrm{~nm}$. This is due to the presence of protein content in pumpkin peel extract which acts as a stabilizing agent.

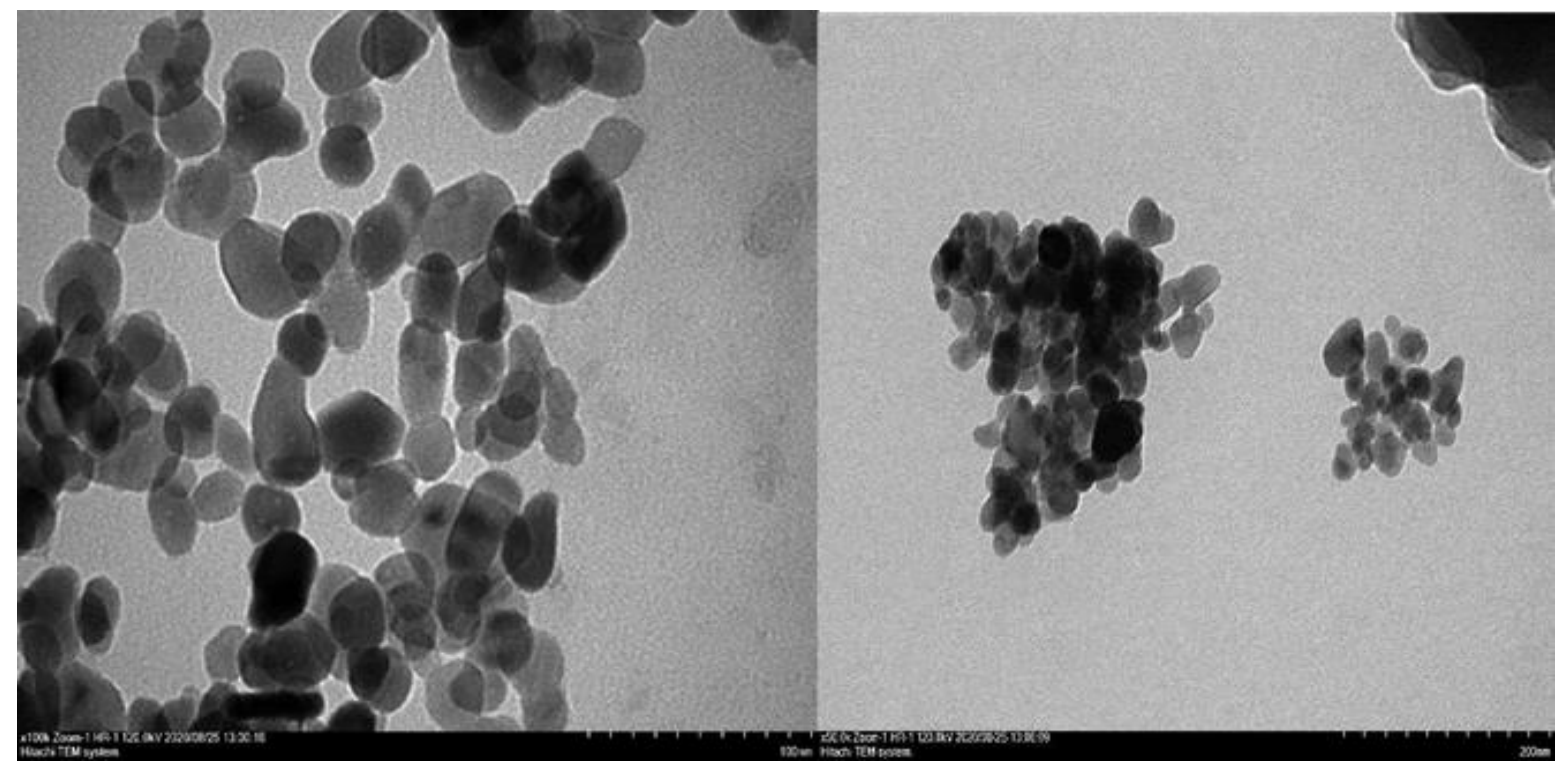

Figure 3. Micrograph TEM of $\mathrm{ZnO}$ Nanoparticles 


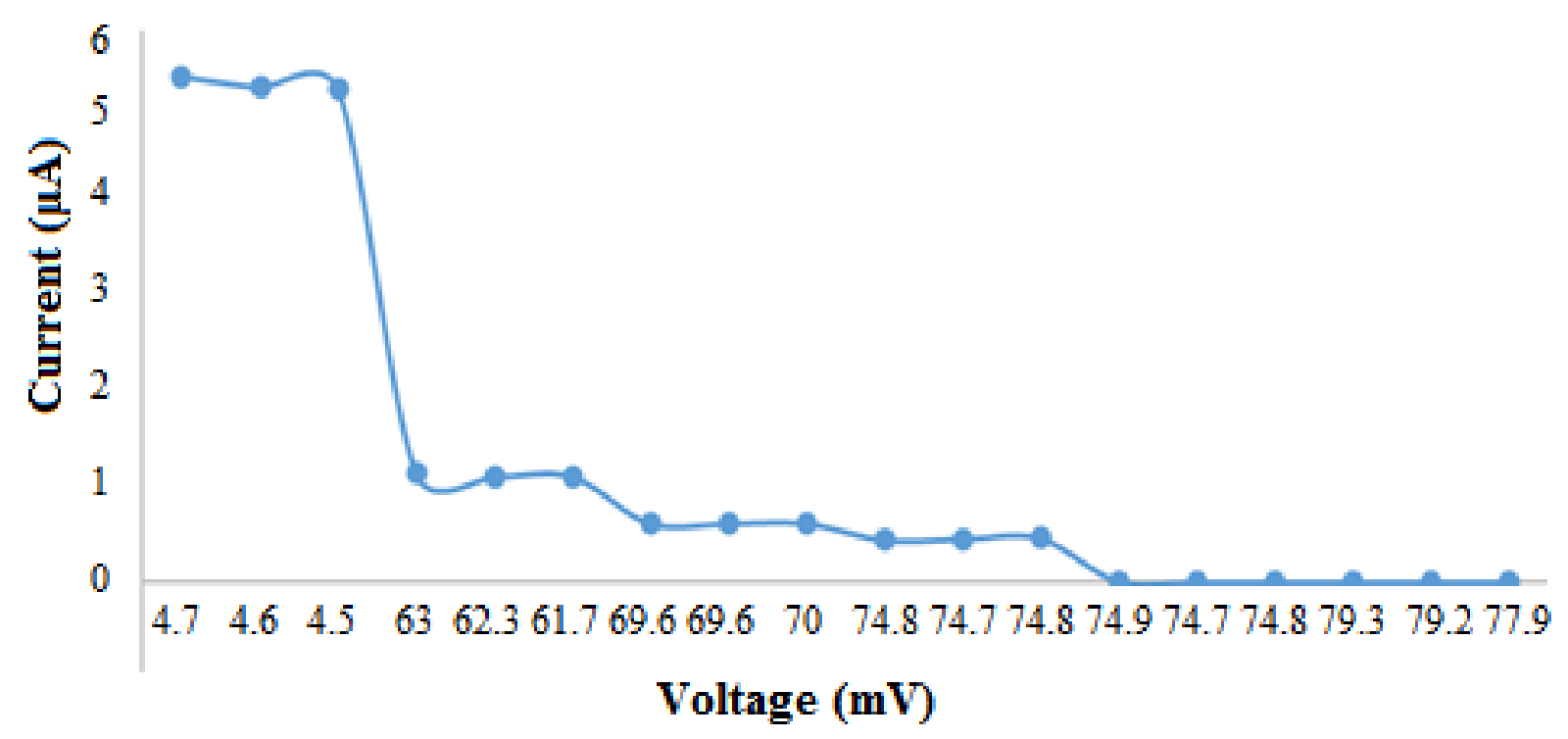

Figure 4. Curve of I-V

By comparing with the results of Nurbayasari et al. (2017) study using Caulerpa $s p$. that produced $\mathrm{ZnO}$ nanoparticles with an average size of $370.72 \mathrm{~nm}$ and (Saridewi et al. (2021) using pumpkin seed extract that produced an average size of $28.07 \mathrm{~nm}$, the results in this study produced $\mathrm{ZnO}$ nanoparticles with a smaller size of $24.90 \mathrm{~nm}$. The smaller the particle size obtained, the greater the effect that will be generated on the DSSC application. The existence of a size effect called the quantum size effect can expand the application of nanomaterials where the smaller the particle size will increase the band gap energy value so as to increase the efficiency of organic solar cells or DSSC(Gratzel, 2003).

The I-V connection characteristic curve has several parameters such as short circuit current $\mathrm{I}_{\mathrm{sc}}$, open circuit voltage $\mathrm{V}_{\mathrm{oc}}, \mathrm{I}_{\max }$ or the current that gives the maximum power value, and $\mathrm{V}_{\max }$ or the voltage that provides maximum power.

In an open circuit (Voc) the solar cell reaches $77.9 \mathrm{mV}$. The magnitude (Voc) produced by the circuit is still in millivolt $(\mathrm{mV})$ units and short circuit current (Isc) 5.51 $\mu \mathrm{A}$. The small current according to Maddu et al., (2007) is due to the resistance of the semiconductor layer and the magnitude of the electrolyte solution. As a result, the electron rate in the semiconductor layer injected from the dye experienced a slowdown. Because the current generated is still small, the maximum power (Pmax) produced is still in milliWatts
$(\mathrm{mW})$ which is $0.01499 \times 10^{-6} \mathrm{~mW} / \mathrm{cm}^{2}$ and fill factor $(\mathrm{FF})=0.1746$ with dye immersion time for 24 hours.

The value (FF) corresponds to the formation of a gentle I-V relationship curve. The most ideal I-V curve is a rectangular box shape, although according to Maddu et al., (2007) a very ideal curve is difficult to achieve because of the resistance of the solar cell. The resulting efficiency is $9.06 \times 10^{-4} \%$. This result is almost the same as Setiawan (2021), where the use of $\mathrm{ZnO}$ nanoparticles using pumpkin seed extract with a DSSC efficiency of $9.03 \mathrm{x}$ $10^{-4} \%$. However, this result is higher than the result of Maryani et al.,( 2012) were use of $\mathrm{ZnO}$ semiconductor synthesized by coprecipitation method, which is $2.25 \times 10^{-4} \%$.

\section{CONCLUSION}

The optimum condition in the biosynthesis of $\mathrm{ZnO}$ nanoparticles is the $\mathrm{Zn}\left(\mathrm{CH}_{3} \mathrm{COO}\right)_{2} .2 \mathrm{H}_{2} \mathrm{O}$ precursor with $\mathrm{pH}$, which produced wurzhite crystals with a hexagonal system and $\mathrm{ZnO}$ nanoparticles measuring at $24.90 \mathrm{~nm}$. The efficiency of DSSC produced from $\mathrm{ZnO}$ nanoparticles with mangosteen peel dye is $9.06 \times 10^{-4} \%$.

\section{ACKNOWLEDGMENT}

The authors extend their gratitude to the Indonesian Ministry of Religion Litapdimas for the 2019 research grant at UIN Syarif Hidayatullah so that the research can be performed properly. 


\section{REFERENCES}

Abdel-latif, M. S., El-agez, T. M., Taya, S. A., Batniji, A. Y., \& El-ghamri, H. S. (2013). Plant Seeds-Based Dye-Sensitized Solar Cells, 2013(4), 516-520.

Al Hakim, R. R. (2020). Model Energi Indonesia, Tinjauan Potensi Energi Terbarukan untuk Ketahanan Energi di Indonesia: Sebuah Ulasan. ANDASIH Jurnal Pengabdian Kepada Masyarakat, 1(1), 11-21.

Alzahrani, E. (2015). Eco-Friendly Production of Silver Nanoparticles from Peel of Tangerine for Degradation of Dye. World Journal of Nano Science and Engineering, 05(01), 10-16.

Azizi, S., Ahmad, M. B., Namvar, F., \& Mohamad, R. (2014). Green biosynthesis and characterization of zinc oxide nanoparticles using brown marine macroalga Sargassum muticum aqueous extract. Materials Letters, 116, 275-277.

Chang, J., \& Waclawik, E. R. (2012). Experimental and theoretical investigation of ligand effects on the synthesis of $\mathrm{ZnO}$ nanoparticles. Journal of Nanoparticle Research, 14(8).

ESDM. (2016). Outlook Energi Indonesia. Dewan Energi Nasional.

Gontijo, L. A. P., Raphael, E., Ferrari, D. P. S., Ferrari, J. L., Lyon, J. P., \& Schiavon, M. A. (2020). $\mathrm{pH}$ effect on the synthesis of different size silver nanoparticles evaluated by dls and their size-dependent antimicrobial activity. Revista Materia, 25(4), 1-10.

Gratzel M. (2003). Dye-Sensitised Solar Cells. Journal of Photochemistry and Photobiology: Photochemistry Review, 2(4), 145-153.

Kilat Permana Putra; Priyono. (2015). Kajian Sifat Struktur Kristal pada Bahan Barium Heksaferit yang Ditambah Variasi $\mathrm{Fe}_{2} \mathrm{O}_{3}$ Menggunakan Analisis Rietveld. Youngster Physics Journal, 4(2), 164-172.

Maddu, A., Zuhri, M., \& . I. (2007). Penggunaan Ekstrak Antosianin Kol Merah sebagai Fotosensitizer pada Sel Surya $\mathrm{TiO}_{2}$ Nanokristal Tersensitisasi Dye. MAKARA of Technology Series, 11(2), 78-84.
Mandal, S., Marpu, S. B., Hughes, R., Omary, M. A., \& Shi, S. Q. (2021). Green Synthesis of Silver Nanoparticles Using Cannabis sativa Extracts and Their Anti-Bacterial Activity. Green and Sustainable Chemistry, 11(01), 28-38.

Maryani, D., Gunawan, G., \& Khabibi, K. (2012). Penentuan Efisiensi DSSC (Dye-Sensitized Solar Cell) yang Dibuat dari Semikonduktor $\mathrm{ZnO}$ yang diemban $\mathrm{Fe} 3+$ Melalui Metode Presipitasi. Jurnal Kimia Sains Dan Aplikasi, 15(1), 29-35.

Maulina, A., Hardeli, \& Bahrizal. (2014). Preparasi Dye Sensitized Solar Celi Menggunakan Ekstrak Antosianin Kulit Buah Manggis (Garcinia Mangostana L). Jurnal Sainstek, 6(2), 158-167.

Nagarajan, S., \& Kuppusamy, K. A. (2013). Extracellular synthesis of zinc oxide nanoparticle using seaweeds of gulf of Mannar, India.

Ningsih, S. K. W., Sanjaya, H., Bahrizal, Nasra, E., \& Yurnas, S. (2021). Synthesis Of $\mathrm{Cu}^{2+}$ Doped $\mathrm{ZnO}$ by The Combination of SolGel-Sonochemical Methods With Duck Egg Albumen As Additive For Photocatalytic Degradation of Methyl Orange. Indonesian Journal of Chemistry, 21(3), 564-574.

Nurbayasari, R., Saridewi, N., Sofwatunnisa. (2017). Biosynthesis and Characterization of $\mathrm{ZnO}$ Nanoparticles with Extract of Green Seaweed Caulerpa sp. Jurnal Perikanan Universitas Gadjah Mada, 19(1), 17-28.

Parajuli, K., Sah, A. K., \& Paudyal, H. (2020). Green Synthesis of Magnetite Nanoparticles Using Aqueous Leaves Extracts of (Azadirachta indica) and Its Application for the Removal of As(V) from Water. Green and Sustainable Chemistry, 10(04), 117-132.

Saridewi, N., Syaputro, H. T., Aziz, I., Dasumiati, D., \& Kumila, B. N. (2021). Synthesis and characterization of $\mathrm{ZnO}$ nanoparticles using pumpkin seed extract (Cucurbita moschata) by the sol-gel method. In $4 T H$ INTERNATIONAL SEMINAR ON CHEMISTRY (Vol. 2349, p. 020010). AIP Publishing.

Setiawan, C. (2021). Sintesis $\mathrm{ZnO}$ Doped $\mathrm{TiO}_{2}$ dengan Ekstrak Biji Labu Kuning 
(cucurbita moschata) untuk Dye-Sensitized Solar Cell (DSSC). [Skripsi]. Jakarta : Universitas Islam Syarif Hidayatullah Jakarta.

Skoog, D.A., Holler, F.J. and Crouch, S. R. (2007). Principles of Instrumental Analysis (Sixth Edit). Belmont: Brooks Cole.

Traiwatcharanon, P., Timsorn, K., \& Wongchoosuk, C. (2017). Flexible roomtemperature resistive humidity sensor based on silver nanoparticles. Materials
Research Express, 4(8), aa85b6.

Yazdani, S., Daneshkhah, A., Diwate, A., Patel, H., Smith, J., Reul, O., ... Hajrasouliha, A. R. (2021). Model for Gold Nanoparticle Synthesis: Effect of $\mathrm{pH}$ and Reaction Time. ACS Omega, 6(26), 16847-16853.

Zobel, M., Chatterjee, H., Matveeva, G., Kolb, U., \& Neder, R. B. (2015). Room-temperature sol-gel synthesis of organic ligand-capped $\mathrm{ZnO}$ nanoparticles. Journal of Nanoparticle Research, 17(5). 